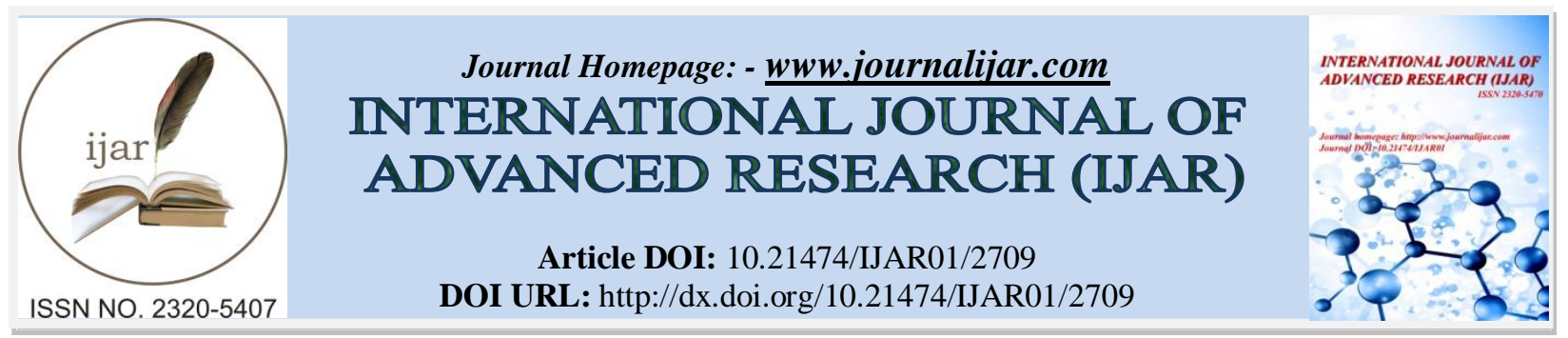

RESEARCH ARTICLE

\title{
BIODIVERSITY, A VITAL RESOURCE THAT NEEDS ASSIDUOUS CONSERVATION EFFORTS AGAINST THE PERIL OF CLIMATE CHANGE.
}

\section{Dr.Swaroopa. Maralla*1 and D. Bharathi ${ }^{2}$.}

1. UGC Post Doc Fellow, Division of Zoology, Department of Sericulture, Sri Padmavati Mahila University, Tirupati-517502, Andhra Pradesh, India.

2. Professor, Department of Sericulture, Sri Padmavati Mahila University, Tirupati-517502, Andhra Pradesh, India.

\section{Manuscript Info}

\section{Manuscript History}

Received: 31 October 2016

Final Accepted: 01 December 2016

Published: December 2016

Key words:-

Climate change, Biodiversity,

Ecosystems, Conservation and Species extinction.

\section{Abstract}

Climate change is an important stressor that can contribute to species extinction. The link between climate change and biodiversity has long been established. Rapid climate change affects the ecosystems as well as the ability of the species to adapt to the ecosystems, and so the biodiversity loss increases. Climate change is already showing a negative impact on biodiversity and is projected to become a progressively more significant threat in the coming decades. Climate change may likely to become one of the most significant drivers of biodiversity loss by the end of the century. Guidance to promote synergy among activities for biodiversity conservation, mitigating or adapting to climate change and combating land degradation is an imminent requirement. The impacts of climate change on biodiversity, ecosystem services and biodiversity-based livelihoods needs to be properly analysed, critically considered and legally protected.

Copy Right, IJAR, 2016,. All rights reserved.

\section{Introduction:-}

Biodiversity or biological diversity denotes the variety or richness of ecosystems, species composition therein, and their genetic diversity too. Biodiversity is indispensable for human survival. Biodiversity provides all basic needs for our healthy survival - oxygen, food, medicines, fiber, fuel, energy, fertilizers, fodder and waste-disposal, etc. Biodiversity is an indispensable resource that needs to be carefully conserved as it holds the key to progress in medicine, agriculture, forestry and other fields.

Biodiversity loss is defined as the long-term or permanent qualitative or quantitative reduction in components of biodiversity and their potential to provide goods and services, to be measured at global, regional and national levels. Biodiversity affects ecosystems at levels comparable to those of global warming and air pollution. Due to population explosion, climate change and lax implementation of environmental policies, several species are facing the threat of extinction. Not only does this affect the food chain, but also the livelihood and the culture of the local communities who depend on local biodiversity.

The major causes of biodiversity decline are land use changes, pollution, changes in atmospheric $\mathrm{CO}_{2}$ concentrations, changes in the nitrogen cycle, acid rain, climate alterations and introduction of exotic species, all

Corresponding Author:- Dr.Swaroopa. Maralla.

Address:- UGC Post Doc Fellow,Division of Zoology, Department of Sericulture, Sri Padmavati Mahila 
coincident to human population growth. The geometric rise in human population levels during the twentieth century is the fundamental cause of the loss of biodiversity.

Loss of species has the potential to reduce plant production just as much as global warming and pollution. The loss of biological diversity may take many forms but the most dramatic aspect is the extinction of species. Loss of biodiversity not only leads to extinction of a given species, but also extinction of the cultural practices and local knowledge associated with that species. Very high rates of modern extinctions--due to habitat loss, over harvesting and other human-caused environmental changes--could reduce nature's ability to accommodate the existing species and their ecosystems.

Ecosystem stability is a compelling reason for preserving biodiversity. All living organisms are an integral part of the biosphere and provide invaluable services. Loss of biodiversity is a much greater threat to human survival than even climate change. Both could act, synergistically too, to escalate human extinction faster. Loss of biological diversity due to species extinctions because of human-inflicted environmental changes adversely affect ecosystem health and productivity.

Elements like plant growth and the decomposition of dead plants by bacteria and fungi will be severely effected by various global environmental stressors. This effects on ecosystem plant growth will result, in changes in species richness of that ecosystem. Global warming and climate change pose threats to plant and animal species as many organisms are sensitive to carbon dioxide concentration in the atmosphere that may lead to their disappearance. Pesticide, troposphere ozone, sulphur and nitrogen oxides from industries also contribute to the degradation of natural ecosystems.

The fragmentation of forests is a general consequence of the haphazard logging and agricultural land conversion which is occurring everywhere, but especially in tropical forests. When forests are cut into smaller and smaller pieces, there are many consequences, some of which may be unanticipated. Fragmentation decreases habitat simply through loss of land area, reducing the probability of maintaining effective reproductive units of plant and animal populations. The use of herbicides and the introduction of exotic species into areas surrounding forest fragments are detrimental to forest health. These invasions drive the loss of indigenous species.

Factors like global warming and increased ultraviolet radiation due to ozone loss in the stratosphere, ozone pollution, acid deposition on forests, soil ecosystems and nutrient pollution affects the species loss.

\section{Threats to biodiversity:-}

The degradation and depletion of biological diversity may largely be attributed to unprecedented pressure that human beings exert on nature. Threats that human activities pose to landscapes, ecosystems and species, can be grouped under the following categories:

\section{Direct pressure:- \\ Over-exploitation of natural resources:-}

High direct and indirect human dependence on natural resources, often leads to over-harvesting of resources. Overexploitation of natural resources for unsustainable consumerism of elite groups on the one hand, while leading to deprivation from or over-exploitation and mismanagement of basic survival resources of ecosystem-dependent communities. The resources of economic importance are utilised to an extent of posing threat to the existence of the species and the population depending on it in the food chain.

\section{Intrusion into habitats:-}

The replacement of entire habitats by settlements, harbors, tourism and other human constructions, or by crop land, grazing land, and plantations, and by mines and quarries; drainage, canalization, and flood control works; pollution and solid waste disposal from domestic, agricultural, industrial, and mining sources; overuse of groundwater aquifers for domestic, agricultural, and industrial purposes; removal of materials such as vegetation, gravel, and stones for timber, fuel, construction, etc.; from ecosystems ; dredging, dumping and erosion are different forms of human intrusion into habitats that adversely affect the ecosystems. 


\section{Indirect pressure:-}

Habitat conversion:-

Unique habitats exist for a wide range of unique flora and fauna. Continuing high levels of extinctions and loss of habitats throughout this century, with associated decline of some ecosystem services important to human wellbeing is rampant. The reasons vary from overuse of resource by humans, climate change, fragmented habitats, habitat destruction, acidification of water/soil or both and more.

\section{Pollution:-}

Recent changes in climate, especially warmer regional temperatures, have already had significant impacts on biodiversity and ecosystems, including causing changes in species distributions, population sizes, the timing of reproduction or migration events, and an increase in the frequency of pest and disease outbreaks.

\section{Introduction of alien species:-}

According to CBD reports, invasive alien species have contributed to nearly 40 per cent of all animal extinction. The spread of invasive alien species and disease organisms has increased because of increased trade and travel, including tourism. Increased risk of biotic exchange is an inevitable effect of globalization. More often it happens that species are introduced unconsciously or by accident. Effects on the local ecosystem may be considerable.

Miscellaneous:- These pressures are enforced by certain human activities such as:

\section{Single-crop agriculture:-}

Agriculture has become incorporated into the global economy, much of it has become part of the global exchange economy and has caused significant changes in social organization. Agricultural land is being diverted from local food production to "cash crops" for export and exchange; fewer types of crops are raised, and each crop is raised in much greater quantities than before. Thus, ever more land is converted from forest (and other natural systems) for agriculture for export, rather than using land for subsistence crops. The introduction of Single-crop agriculture/monocropping and the use of relatively few plants for food and other uses - at the expense of the wide variety of plants and animals utilized by earlier peoples and indigenous peoples - is responsible for the loss of diversity and genetic variability. The native plants and animals adapted to the local conditions are getting replaced with "foreign" (or "exotic") species which require special inputs of food and nutrients, large quantities of water. Such exotic species frequently drive out native species affecting the local biodiversity badly.

\section{Tourism:-}

Unsustainable tourism, is always a great threat to the local ecosystems and tourism now-a-days exert strong pressure on the environment. The greatest danger emerges from both present and planned tourism, which has become one of the main investment areas. Extensive built up by hotels and large tourism resorts that stretch out to the beaches, illegal sand extraction contributes to ecosystem disturbances which further contributes to pollution effects, and socio-economic and cultural disturbances.

\section{Pressure due to global tendencies:-}

Population growth and resource consumption:-

Population growth and our consumption are the reasons for this enormous loss. High population growth experiences rapid changes towards urbanization where demand for agricultural products is expected to increase as income levels in these areas rise. It exacerbates every other factor having an impact on rainforests (not to mention other ecosystems). It has led to an unceasing search for more arable land for food production and livestock grazing, and for wood for fuel, construction, and energy. Previously undisturbed areas are currently being transformed into agricultural or pasture land, stripped of wood, or mined for resources to support the energy needs of an ever-growing human population. Humans also tend to settle in areas of high biodiversity, which often have relatively rich soils and other attractions for human activities. This leads to great threats to biodiversity, especially since many of these areas have numerous endemic species.

\section{Global warming:-}

Global Warming in general (from the effects of increasing concentrations of $\mathrm{CO}_{2}$ and other greenhouse gases), build-up of greenhouse gases in the atmosphere leading to global warming, poses another significant threat to biodiversity, ecosystems, and the goods and services they provide. There are indications that the altered changes in temperature and $\mathrm{CO}_{2}$ concentration may alter growth, reproduction and host-pathogen relationships in both plants 
and animals. It is believed that the species diversity of the ecosystems, as well as their genetic diversity intact, are likely to be in a much better position to face the impact of climate change. These interactions are unimaginably complex.

\section{Challenges of biodiversity conservation:-}

a. Economical Challenges: This sub- head is about including biodiversity into macro economical indicators of countries, promoting economical asset of biodiversity in terms of real value viz., medical and genetic engineering, or profit for activity like eco-tourism, cost of restoration of damaged biodiversity.

b. Management Challenges: Creation of partnership by involving governmental, commercial organisations, navy and military, NGOs, local populations and general public. Promoting ways of societal involvement in ecosystem management, methods for awareness among locals.

c. Legislative Challenges: This discusses biodiversity aspects into all relevant laws, designation of legislation support of biodiversity conservation and developing international agreements and enforcement by governments on local level. Creating firm legal systems and legislation, policies and legal procedures that govern the protection, use and management of natural resources, including living resources.

d. Scientific Challenges: It includes formalization of decision-making procedure, looking for biodiversity indicators, cadastre of biodiversity, development of monitoring and managing systems for the ecosystems and development and designing of conservation strategies.

\section{Measures in biodiversity conservation:-}

Biodiversity includes all ecosystems - wild lands, nature preserves, or national parks, plantations, farms, croplands, aquaculture sites, rangelands and urban parks too have their own biodiversity. Loss in biodiversity has direct and indirect negative effects on food security, vulnerability, health, energy security, clean water and social relations.

Our welfare is intimately connected with the welfare of wildlife; We need to think globally and act locally, rededicating ourselves to protect biodiversity of all the ecosystems viz., forests, coastal ecosystems, ocean, mountain, desert, cave etc., and ecosystems in our own neighborhood. Education, awareness and Increasing community participation making full use of available technologies is a means to get more people involved in biodiversity conservation.

Policymakers addressing solutions to the pressing environmental problems should be well aware of the potential adverse effects on biodiversity as well. An efficient and effective national legislative framework can ensure Legal protection of representative habitat types and help in promoting regulatory processes and activities detrimental to biodiversity.

\section{Conclusion:-}

The conservation of biodiversity, sustainable use of the components of biodiversity, and sharing the benefits arising from the commercial and other utilization of genetic resources in a fair and equitable way should be ratified and promoted.

As a final word, biodiversity management and its interrelations with the ecosystem stability and climate change is complex issue that needs the involvement of many different partners ranging from governmental organisations to private companies, NGO's and volunteers. Besides, national and international commitment, legislation and enforcement offer an essential framework for promoting and maintaining biodiversity.

\section{Acknowledgement:-}

The corresponding author thank the UGC for providing financial assistance under UGC PDFWM Scheme. 


\section{References:-}

1. Plotkin, M.J. (1988). The outlook for new agricultural and industrial products from the tropics. In: E.O. Wilson (ed) Biodiversity. National Academy Press, Washington DC. pp.106-116.

2. Reid, W.V. and Miller, K.R. (1989). Keeping Options Alive: The Scientific Basis for Conserving Biological Diversity. World Resources Institute, Washington DC.

3. Tyler, M.J. (1989). Australian Frogs. Viking O'Neil, Melbourne.

4. Olsen, H.F. (1977). Great Sandy Strait fisheries habitat reserves. In: P. Lauer (ed) Occasional Papers in Anthropology No.8, 223-230. University of Qld, Australia.

5. Ivanovici A.M. (ed). (1983). Inventory of Declared Marine and Estuarine Protected Areas in Australian Waters. ANPWS, Canberra.

6. Iltis, H.H., (1988). Serendipity in the exploration of biodiversity: what good are weedy tomatoes? In: E.O. Wilson (ed) Biodiversity. National Academy Press, Washington D.C. pp.98-105.

7. Beattie, A. (1991). Biodiversity and Bioresources - The Forgotten Connection. Search, Vol 22, No 2, March 1991.

8. McNeely, J.A. (1988). Economics and Biological Diversity. IUCN, Gland, Switzerland.

9. Ecologically Sustainable Development (ESD) Working Group on Tourism. (1991). Ecologically Sustainable Development Working Groups: Final Report - Tourism. AGPS, Canberra.

10. European Environment Agency (EEA), 1995. Europe's Environment, The Dobris Assessment. D. Stanners and P. Bourdeau (eds), E.E.A., Copenhagen.

11. DASETT. (1991). Environmental Tourism. Draft Internal Document, Tourism Policy Branch. DASETT, Canberra.

12. Coombs, H.C., Brandl, M.M. and Snowdon, W.E. (1983). A Certain Heritage. CRES Monograph No.9. ANU, Canberra.

13. Centre Naturopa, "Biodiversity: Questions and Answers", Council of Europe Publishing, F-67075 Strasbourg Cedex, December 1996.

14. Biodiversity Unit, Department of the Environment, Sport and Territories, "Biodiversity and its value", ISBN 0 64219904 3, Commonwealth of Australia, 1993. 